\title{
Characterization of eight polymorphic microsatellite loci for the California spiny lobster, Panulirus interruptus and cross-amplification in other achelate lobsters
}

\author{
Tal Ben-Horin · Matthew Iacchei $\cdot$ Kim A. Selkoe \\ Thien T. Mai $\cdot$ Rob J. Toonen
}

Received: 15 June 2009/Accepted: 25 June 2009/Published online: 15 July 2009

(c) The Author(s) 2009. This article is published with open access at Springerlink.com

\begin{abstract}
Microsatellite sequences were isolated from both non-enriched and enriched genomic libraries of California spiny lobster, Panulirus interruptus. Eight consistently amplifying, scorable and polymorphic loci were characterized for 79 individuals collected at Santa Cruz and San Clemente Islands, California, and tested for crossspecies amplification in four closely related Panulirus spp., as well as four other species of the order Achelata. The number of alleles observed per locus ranged from three to 54 and observed heterozygosities ranged from 0.57 to 0.98 . Quality control testing shows that all loci were reliably scorable, independently segregating, inherited in Mendelian ratios, and had low to moderate $(\leq 14.4 \%)$ frequencies of null alleles and high statistical power for detecting fine scale genetic structure.
\end{abstract}

Keywords Crustacea $\cdot$ Microsatellite .

Panulirus interruptus $\cdot$ Spiny lobster

The California or red spiny lobster, Panulirus interruptus, occurs in shallow, rocky coastal areas from Monterey Bay,

T. Ben-Horin $(\bowtie)$

Donald Bren School of Environmental Science and

Management, University of California at Santa Barbara,

1310 Bren Hall, Santa Barbara, CA 93106-5131, USA

e-mail: tbenhorin@bren.ucsb.edu

M. Iacchei - K. A. Selkoe · R. J. Toonen

Hawaii Institute of Marine Biology, University of Hawaii

at Manoa, Kaneohe, HI 96744, USA

T. T. Mai

Department of Evolution and Ecology, University of California

at Davis, Davis, CA 95616, USA
California to Manzanillo, Mexico, with a small, isolated population in the northern Sea of Cortez (Barsky 2001); however, the majority of the population occurs between Point Conception, California and Bahia Magdalena, Mexico (Duffy 1973). There is significant potential for individuals to disperse across much of this range. After hatching in nearshore waters phyllosome larvae spend seven to nine months drifting in prevailing currents before metamorphosis to the puerulus stage (Serfling and Ford 1975; Engle 1979; Booth and Phillips 1994). Following metamorphosis, pelagic puerulus larvae remain in surface waters for an additional two and a half months before settling to inshore benthic habitats (Shaw 1986). Due to lucrative commercial and recreational fisheries for this species in the United States and Mexico, and the potential impact of these fisheries on the sustainability of lobster populations outside regional management jurisdictions, there is considerable interest in understanding patterns of dispersal and connectivity (Perez-Enriquez et al. 2001; Iacchei et al. 2005). Here we report development of polymorphic microsatellite markers to assess gene flow and infer patterns of connectivity in this species.

Microsatellites were drawn from two different sources. First, a series of 15 potential loci were developed following the Microsatellites for Ecologists protocol (Toonen 1997) as described in Toonen et al. (2004). From roughly 2500 colonies in the initial library, 56 colonies positive for microsatellite-containing inserts were isolated and sequenced, yielding 15 putative microsatellite loci. Of these, 11 contained perfect dinucleotide repeats and four contained compound dinucleotide and/or trinucleotide repeats. The remaining sequences lacked sufficient flanking sequence around the repeat motifs to design primers. Primer 3 (Rozen and Skaletsky 1999) was used to develop primers, and unlabelled primers were ordered from 
Operon Inc., Alameda, CA, USA. These 15 primer sets were tested on 5 individuals from each of 5 sites (Anacapa Island, CA, Santa Catalina Island, CA San Clemente Island, CA San Diego, CA, and Bahia Tortugas, Mexico), and four of the loci were found to be polymorphic, amplify consistently, and be reliably scorable (Pin10, Pin29L, Pin189, Pin244).

The other polymorphic loci were developed from four microsatellite-enriched libraries constructed by Genetic Identification Services (GIS: Chatsworth, CA, USA) using pooled genomic DNA extracted from three adult $P$. interruptus collected off Isla Vista Reef, CA. DNA was isolated from leg tissue stored in $70 \%$ ethanol using a phenolchloroform-isoamyl alcohol protocol followed by isopropanol precipitation (after Toonen 1997). Isolated DNA pellets were washed with $70 \%$ ethanol and re-suspended with $50 \mu$ of sterile $1 \mathrm{X}$ TE buffer, $\mathrm{pH}$ 7.2. Methods for DNA library construction, enrichment and screening followed Jones et al. (2002). A total of 34, 16, 16, and 34 colonies positive for microsatellite inserts were isolated and sequenced from $(\mathrm{GA})_{15},(\mathrm{CATC})_{8},(\mathrm{TACA})_{8}$, and $(\text { TAGA })_{8}$ enriched libraries, respectively yielding $19,6,5$, and 14 putative microsatellite loci. PCR primer pairs were designed for these 44 loci using DESIGNERPCR version 1.03 (Research Genetics, Inc.) and unlabeled primer pairs were ordered from Sigma Proligo, St. Louis, MO, USA. Polymerase chain reactions were performed in $10 \mu \mathrm{l}$ volumes containing $20 \mathrm{ng}$ template DNA, 1x Colorless GoTaq Reaction Buffer (containing $1.5 \mathrm{mM} \mathrm{MgCl} 2 \mathrm{pH}$ 8.5; Promega Corp, Madison, WI, USA), $2 \mu \mathrm{M}$ dNTPs, $6 \mu \mathrm{M}$ forward primer, $6 \mu \mathrm{M}$ reverse primer, and $0.01 \mathrm{U} / \mu \mathrm{l} \mathrm{GoTaq}$ polymerase (Promega Corp.) using a Bio-Rad DNA Engine Dyad Peltier Thermal Cycler (Bio-Rad Laboratories, Hercules, CA, USA). PCR conditions were as follows: $3 \mathrm{~min}$ at $94^{\circ} \mathrm{C}$, followed by 35 cycles of $40 \mathrm{~s}$ at $94^{\circ} \mathrm{C}, 40 \mathrm{~s}$ at annealing temperature (see Table 1 for each locus), $40 \mathrm{~s}$ at $72^{\circ} \mathrm{C}$, and a final extension step of $30 \mathrm{~min}$ at $72^{\circ} \mathrm{C}$. Fourteen primer pairs amplified products of appropriate size and were selected for further study.

For genotyping, PCR amplification was carried out using the conditions described above with forward primers fluorescently labeled with WellRed D2, D3, or D4 dye (Beckman-Coulter Inc., Fullerton, CA, USA; see Table 1 for each primer label). PCR products were sized on a Beckman-Coulter CEQ 8000 capillary sequencer (Beckman-Coulter Inc.). Size markers (Size Standard 400; Beckman-Coulter Inc.) were included in the lane with PCR products and alleles were scored using a CEQ 8000 genetic analysis system (Beckman-Coulter Inc.). Four loci were found to be consistently amplifying, scorable and polymorphic (PinA5, PinA102r, PinA110, PinD110).
These eight loci were tested for conformation to Mendelian expectations using four $P$. interruptus mothers collected at Santa Catalina Island, California and $\geq 8$ attached offspring per mother. A composite chi-squared analysis was used to test for deviations from expected equal inheritance of maternal, heterozygote alleles by offspring. When maternal genotypes were found to be homozygous, we tested for obligate inheritance of the maternal allele in all genotyped offspring. All eight loci passed the composite chi-squared test $(\alpha=0.05)$ and, when applicable, displayed obligate inheritance of maternal homozygote alleles.

Here we report the combined results (Table 1) from two population samples consisting of 79 adult $P$. interruptus collected from Santa Cruz Island and San Clemente Island, California in 2006 and 2007. Micro-CHECKER (van Oosterhout et al. 2004) found no evidence of scoring errors due to stuttering or large-allele dropout. FREENA (Chapuis and Estoup 2007) estimated low $(<10 \%)$ to moderate $(10-15 \%)$ frequencies of null alleles in all loci except PinA5 and Pin10. The presence of low to moderate frequencies of null alleles in these loci is not surprising as this is commonly observed in a variety of abundant marine invertebrate species (Kaukinen et al. 2004). Five loci had significant heterozygote deficiencies (tested in ArLEQuiN 3.11; Excoffier et al. 1995). The severity of the deficits $\left(\mathrm{F}_{\mathrm{is}}\right.$; Fstat 1.2; Goudet 1995) at all loci showed a very strong positive correlation with their average frequency of null alleles estimated in FreeNA $(\rho=0.98, P<0.001)$. This suggests that observed heterozygote deficits result from low to moderate frequencies of null alleles. There was no significant evidence for linkage disequilibrium among pairs of loci following corrections for multiple comparisons (Fstat 1.2; Goudet 1995).

Cross-amplification was tested in four congeneric species in the Panulirus genus, as well as four phylogenetically distant achelate lobsters (Table 2). Of the eight loci tested, five cross-amplified in other lobster species and were found to be polymorphic. All scored alleles in these samples were within the size range of scored alleles observed in P. interruptus. One locus, Pin189, was found to be monomorphic in the phylogenetically distant Parribacus antarcticus, and the scored allele in these samples was outside the size range of alleles found in P. interruptus. Cross-amplification was otherwise only observed in Panulirus spp.

The capacity for these loci to detect fine-scale patterns of population structure was evaluated using the simulationbased power analysis Powsim (Ryman and Palm 2006). Simulation results estimate $94 \%$ statistical power in detecting fine-scale population structure $\left(F_{\mathrm{ST}}=0.01\right)$ with 30 individuals sampled from each subpopulation. 


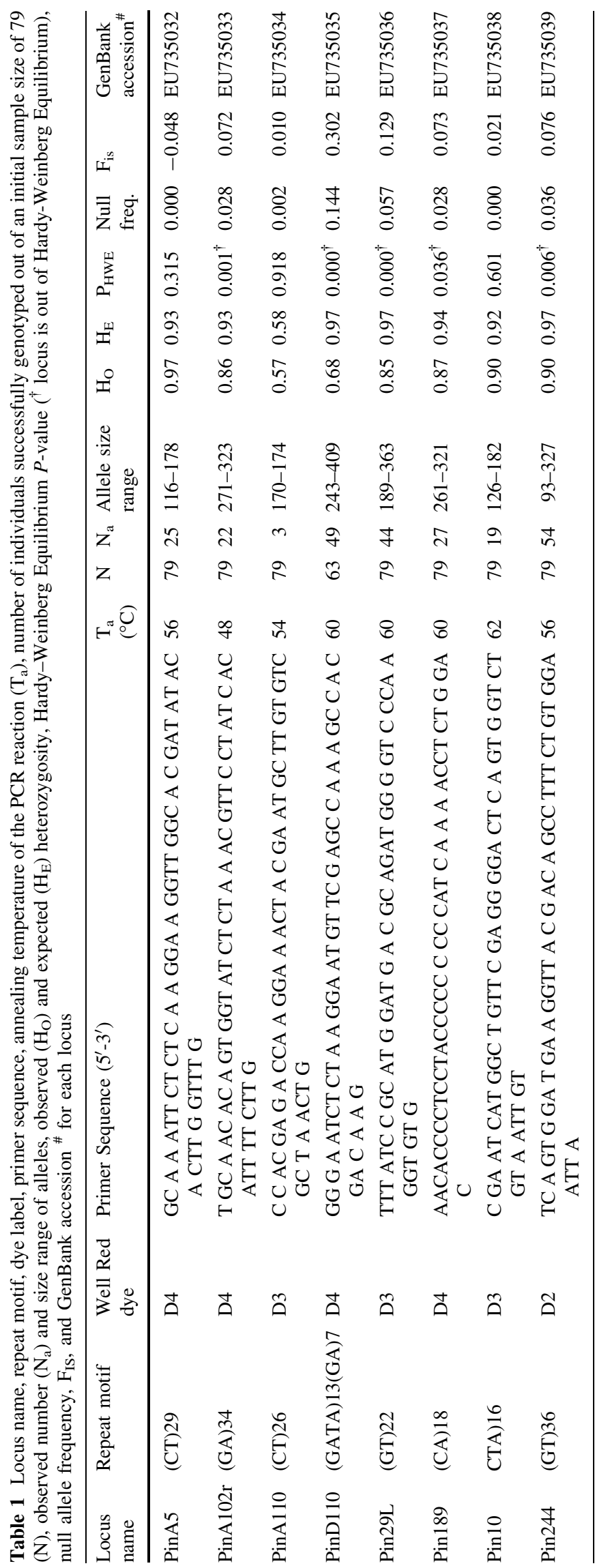


Table 2 Cross-amplification of the eight microsatellite loci in eight additional lobster species

\begin{tabular}{|c|c|c|c|c|c|c|c|c|}
\hline & PinA5 & PinA102r & pinA110 & pinD110 & Pin29L & Pin189 & $\operatorname{pin} 10$ & Pin244 \\
\hline Panulirus marginatus (4) & 0 & 3 & 0 & 2 & 4 & 4 & 0 & 0 \\
\hline Arctides regalis (4) & 0 & 0 & 0 & 0 & 0 & 0 & 0 & 0 \\
\hline Scyllarides haanii (4) & 0 & 0 & 0 & 0 & 0 & 0 & 0 & 0 \\
\hline Panulirus penicillatus (4) & 0 & 0 & 0 & 0 & 3 & 4 & 4 & 0 \\
\hline Panulirus inflatus (1) & 0 & 0 & 0 & 0 & 0 & 0 & 0 & 0 \\
\hline Parribacus antarcticus (4) & 0 & 0 & 0 & 0 & 0 & $2^{*}$ & 0 & 0 \\
\hline Scyllarides squammosus (4) & 0 & 0 & 0 & 0 & 0 & 0 & 0 & 0 \\
\hline Panulirus versicolor (2) & 0 & 0 & 0 & 0 & 2 & 0 & 0 & 0 \\
\hline
\end{tabular}

The number of individuals tested for each species is indicated by the number in (). Numbers in columns indicate the number of samples amplifying polymorphic products of comparable size to that amplified from $P$. interruptus. 0 indicates no amplification of any products.

* indicates amplification of monomorphic products outside the size range of products amplified from $P$. interruptus

Statistical power is increased to $99 \%$ when sampling is increased to 50 individuals from each subpopulation. Measures of population genetic structure, such as $F_{\mathrm{ST}}$, may be overestimated in the presence of null alleles when populations are substantially differentiated. This bias diminishes as gene flow between populations increases (Chapuis and Estoup 2007). Larval exchange among populations of Panulirus interruptus is potentially extensive, and consequently, patterns of genetic differentiation are likely to be subtle. These eight loci therefore provide sufficient variability and statistical power to address this finescale and complex population structure, providing a useful set of molecular markers to address questions of connectivity in this highly valuable fishery species.

Acknowledgements We are grateful to M.Todd of Genetic Identification Services for library construction and microsatellite identification. Creation of the initial microsatellite library was made possible by R. Grosberg. We thank P. Robinson for assistance in collecting tissue and egg samples from Santa Catalina Island, J. Wible, S. Adams and K.A. Miller for collecting the San Clemente Island tissue samples, D. Kushner for the Anacapa Island samples, A. Ramirez-Valdez for northern Baja, Mexico samples, T. Wahab for northern Channel Island samples, and F. Garcia-Rodriguez for providing tissue samples from Bahia Tortugas, Mexico. We appreciate assistance from S. Bogdanowicz, A. Vogel, K.A. Miller, and members of the Toonen-Bowen lab in the preliminary testing of microsatellite primers. This project was partially supported by funding from the University of California Coastal Environmental Quality Initiative, the Offield Family Foundation, an EPA STAR Fellowship (to M.I.), and National Sea Grant NA06RG0142, project R/F-177 to R. Grosberg \& R.J.T. This is contribution number 242 from the University of Southern California's Wrigley Marine Science Center, SOEST 7475 and 1317 from the Hawaii Institute of Marine Biology. EPA has not officially endorsed this publication and the views expressed herein may not reflect the views of the EPA.

Open Access This article is distributed under the terms of the Creative Commons Attribution Noncommercial License which permits any noncommercial use, distribution, and reproduction in any medium, provided the original author(s) and source are credited.

\section{References}

Barsky KC (2001) California spiny lobster. In: California's living marine resources: a status report. California Department of Fish and Game Agriculture and Natural Resources Communication Services. Oakland, CA

Booth JD, Phillips BF (1994) Early life history of spiny lobster. Crustac 66:271-294

Chapuis MP, Estoup A (2007) Microsatellite null alleles and estimation of population differentiation. Mol Ecol Evol 24:621-631

Duffy JM (1973) The status of the California spiny lobster resource. Calif Dept Fish Game Mar Res Tech Rep 10:1-15

Engle JM (1979) Ecology and growth of juvenile California spiny lobster (Panulirus interruptus Randall). PhD Thesis, University of Southern California, Los Angeles, CA

Excoffier L, Laval G, Schneider S (2005) Arlequin ver. 3.0: An integrated software package for population genetics data analysis. Evol Bioinf Online 1:47-50

Iacchei M, Robinson P, Miller KA (2005) Direct impacts of commercial and recreational fishing on spiny lobster, Panulirus interruptus, populations at Santa Catalina Island, California, United States. NZ J Mar Fresh Res 39:1201-1214

Jones KC, Levine KL, Banks JD (2002) Characterization of 11 polymorphic tetranucleotide microsatellites for forensic applications in California elk (Cervus elaphus canadensis). Mol Ecol Notes 2:425-427

Kaukinen KH, Supernault KJ, Miller KM (2004) Enrichment of tetranucleotide microsatellite loci from invertebrate species. J Shel Res 23:621-626

Perez-Enriquez R, Vega A, Avila S, Sandoval JL (2001) Population genetics of red spiny lobster (Panulirus interruptus) along the Baja California Peninsula. Mexico Mar Fresh Res 52:15411549

Rozen S, Skaletsky HJ (1999) Primer3 on the www for general users and for biologist programmers. In: Krawetz S, Misener S (eds) Bioinformatics methods and protocols: methods in molecular biology. Humana Press, Totowa, NJ, USA, pp 365-386

Ryman N, Palm S (2006) POWSIM: a computer program for assessing statistical power when testing for genetic differentiation. Mol Ecol Notes 6:600-602

Serfling SA, Ford RF (1975) Ecological studies of the puerulus larvae stages of the California spiny lobster, Panulirus interruptus. Fish Bull 73:360-377

Shaw WN (1986) Species profiles: life histories and environmental requirement of coastal fishes and invertebrates (Pacific 
Southwest)—spiny lobster. U.S. Fish Wildl. Serv. Biol. Rep. 82. U.S. Army Corps of Engineers, TR EL-82-4. 10 pp

Toonen RJ (1997) Microsatellites for ecologists: non-radioactive isolation and amplification protocols for microsatellite markers. http://www2.hawaii.edu/ toonen/files/MsatsV1.pdf
Toonen RJ, Locke M, Grosberg R (2004) Isolation and characterization of polymorphic microsatellite loci from the Dungeness crab Cancer magister. Mol Ecol Notes 4:30-32

Valsecchi E (1998) Tissue boiling: a short-cut in DNA extraction for large-scale population screenings. Mol Ecol 7:1243-1245 